\title{
The Third Neighbour Policy and Australia ${ }^{1}$
}

\author{
Ts. Batbayar (M ongolia)
}

$\mathrm{D}$ istinguished scholars, researchers and students, Ladies and gentlemen, First of all, I want to sincerely thank the ANU for inviting me to the Second Open Conference on Mongolian Studies in this very esteemed world-class university. Few universities have produced so many eminent persons, including Nobel Prize laureates. It is even more endearing that the ANU founded a Mongolian Studies Centre in 2011.

Let me begin by saying a few words about Mongolia's democratic transition and the present developments in the country.

Following seven decades of Communist rule, Mongolia's peaceful Democratic revolution in 1990 ushered in a transition from a single-party Communist system with strong ties to the Soviet Union to a multiparty democracy without bloodshed or shattering a single window. In 1992, Mongolia adopted its first democratic Constitution and held the first free elections to the newly established State Great Khural. Since that time, we held six successful rounds of parliamentary elections.

Mongolia has made great strides in its democratic and economic transformation. We have come to be recognized worldwide as a vibrant democracy. We have fundamentally changed our old political and socio-economic structure and built a new democratic system that respects market economy, free elections, media freedom and civil society. Democratic values, human rights and freedoms and market economy rules are now deeply embedded in the society.

Mongolia has passed the most challenging period of democracy. But many problems persist. However, what is most important is that every Mongolian knows what it feels like to speak freely, elect public officials, enjoy both opportunities and challenges of market economy and have his/her private property rights protected. This taste of freedom is sometimes bitter, but we would not want to give it up for anything else.

Furthermore, as a member of the international community, Mongolia is committed to promoting democracy and protecting human rights and freedoms. We successfully chaired the Community of Democracies for the years 2011-

1 Second Open Conference on Mongolian Studies, Australian National University 4 November 2013 
2013, a global intergovernmental coalition of over 130 democratic countries with the goal of promoting democratic norms and institutions around the world. We hosted the $7^{\text {th }}$ Ministerial Conference of the CoD this year along with the $\mathrm{CoD}$ Parliamentary Forum, Youth Forum, Civil Society Forum and the Corporate Democracy Forum, which is a private business pillar of the Community.

Mongolia's economic transition has also been relatively successful. Our economy was in a wreck over 20 years ago. However, as a result of consistent economic policies and driven by the mining boom, Mongolia officially moved from the low-income countries list to "lower middle-income country" status in 2011. For the past few years, it has even been one of the world's fastest growing economies. Our economy grew by an unprecedented 17.5 per cent in 2011 . The growth moderated to 12.3 percent last year after global economic slowdown weakened demand for Mongolia's main export commodities. This steady growth has captured the attention of political and business interests worldwide.

Mongolia is now at a crucial turning point. Its future prosperity is affected by a range of highly uncertain drivers of change, including the reliability of foreign investments and fluctuating commodity prices. It faces unprecedented opportunities for economic development, but also substantial risks, such as falling under the resource curse.

Our priority now is to maintain high growth rates and use them to develop a diversified economy that creates value locally. This is potentially within our reach as we have started major infrastructure and industrial development while continuing our mining projects, such as the development of the world's largest new source of copper Oyu Tolgoi.

\section{Foreign policy}

The identity of Mongolia's foreign policy has been based on its geopolitical position, especially its landlocked location between two powerful nations - China and Russia.

With the Democratic revolution, Mongolia adopted a peaceful, open, independent and multi-pillar foreign policy enshrined in the 1992 Constitution and the 1994 Concepts of National Security and Foreign Policy. The Constitution prohibited the stationing and transitioning of foreign troops through Mongolia's territory. In its Foreign Policy Concept, Mongolia pledged to "pursue a policy of refraining from joining any military alliance or grouping, allowing the use of its territory or air space against any other country, and the stationing of foreign troops or weapons, including nuclear or any other type of mass destruction weapons in its territory". 
The 1994 Foreign Policy Concept further stated that "maintaining friendly relations with China and Russia shall be the top priority of Mongolia's foreign policy, and Mongolia shall not align to either country, but rather develop balanced relations with both of them and promote all-round good-neighbourly cooperation". The Concept further stated that the second priority of Mongolia's foreign policy shall be developing friendly relations with developed countries in the East and West. This was a clear implication of Mongolia's 'third neighbour' policy, which I will talk about soon.

One might wonder why Mongolia's fundamental documents are so much focused on the principle of non-alignment to either of its two neighbours. It all boils down to Mongolia's history and the crucial lesson it taught us. Mongolia was under the Manchu rule in the $18^{\text {th }}$ and $19^{\text {th }}$ centuries. When the Manchu collapsed, Mongolia came under Moscow's expanding influence. From 1921 until 1990, Mongolia was a close ally of the Soviet Union, with its foreign policy in alignment with Moscow's. During the period of Sino-Soviet enmity from the mid-1960s to 1989, the Soviet Union even stationed troops and military equipment in Mongolia.

Therefore, Mongolia learned all too well that in order to survive it should keep balanced relations with both its neighbours, without aligning to either. If Mongolia were to align itself too closely to either of them, it would surely spark alarm. Should it lean too far toward Moscow or Beijing, the other would see Mongolia as a territorial buffer subject to exploitation by the other side.

We have treaties on friendship and cooperation with both China and Russia. Those treaties lay down the basic principles of cooperation, including mutual respect for each other's independence, sovereignty and territorial integrity, nonaggression, non-interference in each other's internal affairs, peaceful co-existence and equality in relations.

The past few years marked a very important development in our relationship with China and Russia. We have established strategic partnership with both of them. We consider strategic partnership as the highest level of cooperation.

Given Mongolia's geographic position, it is only natural that our relationship with China and Russia is our top foreign policy priority. Furthermore, being landlocked, we are dependent on them for land access to the global markets. China's Tianjin Port is Mongolia's main route to the Asia Pacific. And Russia is our main route to Europe.

China has been our largest trade and investment partner for over a decade. It is our biggest export partner. In 2012, around 92 per cent of all exports went to China, while around 27 per cent of all imports originated there. Minerals are Mongolia's main export to China.

Despite being our biggest import partner, Russia is lagging behind China in terms of overall trade and investment into Mongolia. Around 27 per cent of all 
Mongolia's imports came from Russia in 2012, although only 1.8 per cent of the country's exports went the other way. Mongolia meets almost its entire demand for oil products through imports from Russia.

Despite less substantial volume of bilateral trade and investment, Mongolia and Russia share close historic ties. One important part of that legacy is the fact that hundreds of thousands of Mongolians have received their higher education degrees in Russia.

\section{'Third neighbour' policy}

Ever since it embraced an independent foreign policy in the early 1990s, while trying to ensure active and balanced relations with its two immediate neighbors, Mongolia has focused on developing close ties with states that do not border it, but which serve as metaphorical 'third neighbors'. The 'Third neighbor' policy is the incarnation of Mongolia's new foreign policy following the socialist era.

The purpose of the 'third neighbour' policy is to maintain Mongolia's national security with the support of not only our two big neighbors but some other influential countries. It is a policy of simultaneous and parallel development of cooperation with our two big neighbors and other friendly countries. It is also a policy that helps us not to be dependent on any particular country or countries.

Mongolia's 'third neighbor' policy is designed to improve its flexibility in international affairs by tying interests of its two neighbors and other partners. It is an effort to ensure that we have close relations with as many actors as possible, not just Russia and China.

The term 'third neighbor' was first mentioned by U.S. Secretary of State James Baker during his visit to Mongolia in 1990. Baker declared the United States to be Mongolia's 'third neighbor'. The concept was picked up by Mongolian policymakers and eventually became formalized in its foreign policy and legislation.

It is important to stress that the 'third neighbour' policy does not mean any kind of disregard or denial of our two neighbours. On the contrary, it is a policy of implementing the priority of deepening relations with China and Russia and at the same broadening cooperation with other countries.

It is not that we expect any of our 'third neighbors' to intervene, should there be any misunderstanding with our physical neighbors. Again, the vital component of the 'third neighbour' policy is to maintain strategic partnership with our two immediate neighbors. It is just that Mongolia is trying to maintain a situation where there are many foreign players and they all have a stake in Mongolia.

Mongolia does not have land connection with its 'third neighbours', but it has values connection. Common democratic values are at the heart of Mongolia's 
relationship with its 'third neighbours'. In this sense, the 'third neighbours' are primarily those countries that have consistently supported democratic change in Mongolia. Therefore, Australia has been one of our 'third neighbours' from the very start.

It needs to be mentioned that the 'third neighbour' policy is not only about politics. It also helps us diversify our foreign trade and investment. Here, I am pleased to note that Mongolia's economic linkages with its 'third neighbours' are growing more and more. For example, Canada is our largest export partner after China. The US, Japan and the ROK are our largest import partners after Russia and China. Singapore, Canada, ROK, US, Hong Kong, Australia and Japan are among our top 12 investment partners.

Mongolia is trying to integrate its economy with its 'third neighbours'. Our 'third neigbours' play a critical role in bringing financial capital, high technology, and much-needed eco-friendly strategies and management to Mongolia. We are now very much focused on expanding our rail and road networks to better connect to our immediate and 'third neighbours'. With these transit corridors, Mongolia can become a bridge connecting Europe and Asia and the shortest destination to either of them.

\section{Prototype of the 'third neighbour' policy}

It needs to be noted that the "third neighbor" policy is not completely new to Mongolia. Just after Mongolia's liberation from the Manchu rule in the early 19th century, our leaders tried to establish good relationships with Western countries and Japan. They sent letters to the US, Japan, the United Kingdom, Germany, France and the Netherlands seeking their support in protecting Mongolia's newly restored sovereignty. Our Government even tried sending its official delegation to those countries to secure formal recognition of Mongolia's independence. This was the search of 'third neighbors' by our founders of the independent Mongolia in 1911.

But from 1921 to 1990, when Mongolia was engulfed in the socialist system, there was neither need nor opportunity to seek 'third neighbors' due to the Soviet Union's undivided dominance in Mongolia's domestic and foreign policy.

\section{The 2011 Foreign Policy Concept}

Mongolia's foreign policy imperatives were all duly reflected when Mongolia updated its Foreign Policy Concept in 2011 in light of the fundamental changes the world and Mongolia itself have undergone since 1994. The second foreign policy concept is not completely a new one, but largely the same old concept but 
adapted to today's world realities. However, it leaves intact the same priorities of cultivating closer relations with our two physical neighbours and 'third neighbours'.

The revised Foreign Policy Concept sets 5 priorities for Mongolia's foreign policy, which are as follows:

1. Given Mongolia's unique geographic location, it is only natural that maintaining friendly and balanced relationship with the two neighbours remains our top priority.

2. The second priority is to "develop and expand partnership relations and cooperation with countries and blocs of countries in the East and West in the framework of the 'third neighbor' policy". This way, the Concept officially declared the 'third neighbor' policy of Mongolia for the first time in its history.

3. The third priority is to further develop bilateral relations and cooperation with other Asian countries, participate in multilateral cooperation in the Asia-Pacific region, as well as support efforts to strengthen strategic stability and expand security cooperation in East Asia, Northeast Asia and Central Asia.

4. The fourth priority is to continue our active cooperation with the United Nations, its specialized agencies, as well as international financial, trade and economic organizations, and support efforts to increase the role of the UN in global governance.

5. The fifth priority is to strengthen our bilateral relations with developing countries, including in the framework of the UN, G77 and the NonAligned Movement.

\section{The 'third neighbour' policy impact}

The 'third neighbor' policy has been both a political and economic success. In the early 1990s, when Mongolia began political reforms, the support of Western countries was crucial to its democratic transition. Also, donor countries helped Mongolia overcome its economic hardships after the sudden end of Soviet aid.

Currently, Mongolia has established strategic partnership with Japan. We are developing comprehensive partnerships with Germany, India, the Republic of Korea, Turkey and the US, as well as an expanded partnership with Australia, Canada and Kazakhstan.

Just within last month, we received the state visit of the Governor General of Canada David Johnston, as well as the official visits of the Deputy President of the Republic of South Africa Kgalema Petrus Motlanthe, British Secretary of State for Foreign and Commonwealth Affairs William Hague and French Foreign Minister Laurent Fabius. German Chancellor Angela Merkel visited Mongolia in 2011. US 
Vice President Joe Biden and the then-Secretary of State Hillary Clinton visited Mongolia in 2011 and 2012, respectively. These were the highest level visits by the US since President George W Bush visited in 2005, with Secretary of State Madeline Albright visiting earlier in 1998, indicating the renewed significance of Mongolia in Washington, as well as reflecting its growing investor interest. Mongolia and the United States of America have recently signed an Agreement on Transparency in Matters Related to International Trade and Investment.

Summit level visits with Japan and the Republic of Korea are even more frequent. The Presidents of the ROK visited Mongolia in 2006 and 2011, respectively. The Prime Ministers of Mongolia and Japan exchanged official visits this year. In 2012, we started official talks with Japan to establish our first Economic Partnership Agreement.

Relations with the EU have also advanced, with the EU and Mongolia signing a Cooperation and Partnership Agreement in April this year. Mongolia could be useful to the EU as a gateway to Northeast Asia. The trans-Mongolian rail route is part of the shortest rail link between Europe and Beijing.

Mongolia's relationship with its two immediate neighbours and 'third neighbours' has taken on a new interesting dimension in recent years due to its rich mining deposits. Mongolia has become an arena where economic interests of great powers and multinational corporations overlap.

Furthermore, people-to-people exchange is a very important part of Mongolia's engagement with its 'third neighbours'. Around 100,000 Mongolians live and work abroad, with most of them currently in 'the third neighbor' countries and regions like the U.S., Europe, Japan and the ROK.

\section{International and regional organizations and mechanisms}

I would like to clarify that the 'third neighbour' concept is not confined to a community of countries. It also includes international and regional organizations. Mongolia is a member of the UN and international financial, trade and economic institutions. Such membership has significantly contributed to Mongolia's socioeconomic development. Last November, Mongolia made history when it became the $57^{\text {th }}$ participating State of the Organization for Security Cooperation in Europe. Furthermore, we are one of NATO's global partners, as well as an observer in the Shanghais Cooperation Organization.

We actively participate in the major multilateral fora. We are a member of the ASEAN Regional Forum (ARF), Asia-Europe Meeting (ASEM), Asia Cooperation Dialogue (ACD) and the Pacific Economic Cooperation Council (PECC). Being an Asia-Pacific country with a growing economy, Mongolia has an enduring aspiration to become a member of APEC, for which Australia's 
support would be critical. Our regional agenda is also centered on becoming a dialogue partner of ASEAN and joining the East Asia Summit process.

I would also like to note that as a member of the international community, Mongolia has made its own contribution to the missions of the international and regional organizations mentioned above. Since 2002, Mongolia has deployed troops to the UN peacekeeping operations in Africa as well as U.S. and NATOled coalition operations in Afghanistan, Iraq and Kosovo. Given its population of around 2.8 million and the small size of its military, Mongolia's commitment to peace and security is substantial. It is one of the top 20 troop contributing countries for the UN peacekeeping.

\section{Mongolia and Australia}

Let me now turn to the relations between Mongolia and Australia. Last year, the two countries celebrated the $40^{\text {th }}$ anniversary of diplomatic relations established back in 1972 amid the Cold War. We are proud to say today that Australia is one of our major partners in the Asia-Pacific region.

There was little interaction between the two nations for many years until Mongolia's democratic paved the way for closer engagement. The GovernorGeneral of Australia paid an official visit to Mongolia in 1994. Mongolian President Ochirbat and Prime Minister Batbold visited Australia in 1997 and 2011, respectively. The Prime Minister's visit witnessed the signing of the Intergovernmental Memorandum of Understanding (MOU), MOU on Supporting Agricultural Development, Agricultural Technologies and Exchange of Information, MOU on Cooperation in the Field of Vocational Education, MOU between the Mongolian and Australian Academies of Science and the MOU on Cooperation between the National University of Mongolia and the Australian National University.

This was followed by the visits of the Australian Foreign Ministers in 2007 and 2012. It was during the 2007 visit that the two Sides agreed to bring their relationship to the level of "expanded partnership".

Mongolia opened its embassy in Canberra in 2008, while Australia opened its Trade Representative's Office and Consulate-General in 2011 and 2012, respectively. These events show our growing bilateral relationship. They also marked an important step in opening new opportunities for cooperation. Mongolia remains hopeful that as the bilateral relationship deepens, Australia would open its embassy in Mongolia.

The inter-parliamentary cooperation has been also growing, with many mutual visits by both countries' parliamentarians. 
The Mongolians are deeply grateful to the people and Government of Australia for their consistent support throughout its democratic transition. We profoundly value the Australian Government's official development assistance in the areas of capacity building, environment and healthcare. Australia extended its helping hand when Mongolia was hit in 2000 and 2010 by the dzud, which is abnormally cold winter that cause livestock to freeze and die en masse, destroying the livelihood of herding families.

The bilateral trade turnover has been growing steadily and reached around 544 million USD in 2012. However, as the trade turnover is growing, so is the trade imbalance with our exports standing at 464 million USD and imports - at 80 million USD in 2012. Mongolia exports textiles, including carpets, cashmere goods to Australia, and imports sugar, heavy machinery parts and mining equipment.

The two areas that truly underpin our bilateral relationship are the Australian educational investment and the substantial engagement of Australian businesses in the Mongolian mining industry.

Education is, indeed, the most promising sector of our cooperation. We are deeply grateful to Australia for its continued scholarship program for Mongolian nationals. Since 1994, over 300 Mongolians have done graduate or post-graduate studies under the Australian Government scholarships. These scholarships have definitely strengthened Mongolia's public administration. I am very pleased to note that Mongolian graduates of Australian institutions advance to middle and higher level posts, and are great advocates of closer ties between our two countries.

Mining is the second area that underpins Mongolia-Australia cooperation. In 2009, the Mongolian Government and the British-Australian Rio Tinto signed a multi-billion dollar Investment Agreement to develop one of the world's largest copper-gold reserves Oyu Tolgoi, whereby the latter owns 66 percent of the mine, while the Government holds the remaining 34\% stake. According to some estimates, the mine will generate up to one-third of Mongolia's GDP when it reaches full production in 2020-2021. The Oyu Tolgoi project has tremendous significance for Mongolian-Australian bilateral relationship.

However, it needs to be mentioned that Oyu Tolgoi is currently stalled on some disagreements between our Government and Rio Tinto that include the financing of the mine's second-stage or underground expansion. The dispute has led to the suspension of the expansion and the layoff of about 1,700 workers. The two Sides have been in talks for months to settle their differences and have made some progress. We are confident that comprehensive agreement will be reached very soon, as the stakes are too high for both Sides. 
Despite the geographic distance, Mongolia and Australia have a lot in common, such as sparsely populated vast territories, rich natural resources and livestock, as well as active participation in the UN peacekeeping.

With such similarities, Australia is ultimately a developmental model for us. There have been a number of government study group visits to Australia to learn its experience in how to rationally use mining revenues for the country's development and create a better legal and institutional framework for mining investments. We are grateful that Australia included Mongolia in its Mining for Development Initiative. Mongolia is very much keen to continue to learn from Australia's great experience in the mining industry.

One of the important parts of Mongolia-Australia expanded partnership is their continued cooperation in the international arena. Mongolia and Australia share common positions on a wide range of international issues and have supported each other accordingly. Both countries support non-proliferation, disarmament, peacekeeping and human security norms. Both are members of the Asia-Europe Meeting, the ASEAN Regional Forum and global partners of NATO.

As you can see, Mongolia and Australia share something beyond political and economic ties. We share common democratic values and similar economic structures. I strongly hope that we will further expand our bilateral relationship drawing on those values.

Thank you for attention. 